\section{Omfattende, men ujevnt, om kommunikasjon}

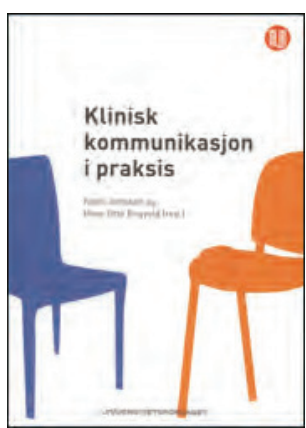

Denne boken er dedikert til professor Even Lærum, som avsluttet sitt virke som praktiserende lege i 2013. Redaktørene har bakgrunn fra Formidlingsenheten for muskel- og skjelettlidelser som Lærum har ledet ved Oslo universitetssykehus.

De 24 bidragene kommer fra like mange forfattere, og de gir en mangfoldig presentasjon av kommunikasjon i klinisk medisin i Norge i dag. Her er omtale av sentrale temaer, eksempelvis kommunikasjonsmodeller, herunder «fire gode vaner» som sikrer effektiv kommunikasjon, presentasjon av motiverende intervju, kroppen i klinisk kommunikasjon, tillit i helsevesenet, holdning til samtalen og helsefremmende tverrfaglig kommunikasjon. Videre tar bidragsyterne opp møtet med spesielle pasientgrupper og spesielle situasjoner, som samtale med barn og eldre, vanskelige relasjoner, hypokondri, møte med voldsutsatte, alvorlig syke, flerkulturelle pasienter, ved fare og død og når legen har gjort feil. Det er også korte presentasjoner av terapiformer som kognitiv terapi og hypnoterapi.

Mange av kapitlene er godt skrevet, og noen er en fornøyelse å lese. Men mangfoldet blir en svakhet når redigeringen, i det minste for meg, virker fraværende. Det er krevende å redigere korte bidrag fra så mange forfattere. Flere av bidragene synes jeg hadde trengt klare råd om forbedring. Noen sentrale temaer og referanser er utelatt. Som leser med bakgrunn fra allmennmedisin savner jeg omtale av vanlige begreper og modeller som er sentrale i kommunikasjonsundervisning i allmennmedisin ved flere norske fakulteter. Et sentralt eksempel på dette er pasientsentrert klinisk metode, med referanse til forfattere som McWhinney og Silvermann.

Redaktørene ser denne utgivelsen som en bredt sammensatt fag- og lærebok i kommunikasjon for grunn- og etterutdanning av leger og annet helsepersonell. Jeg synes boken er av interesse for helsepersonell med spesiell interesse for kommunikasjon, som en oppdatering på hvordan en sentral gruppe aktører med basis i institusjonsmedisin tenker og arbeider. Boken er mindre egnet som lærebok i grunnutdanningen av leger eller videreutdanningen i allmennmedisin. Til det er den for ujevn og mangler vesentlige bidrag fra norsk og internasjonal allmennmedisin.

Per Stensland

Professor, Institutt for global helse og samfunnsmedisin Universitetet i Bergen

\section{Kort og godt om kunnskapsbasert praksis}

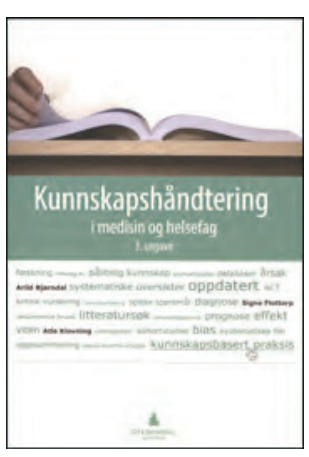

Arild Bjørndal, Signe Flottorp, Atle Klovning Kunnskapshåndtering i medisin og helsefag 3. utg. 194 s, tab, ill, Oslo: Gyldendal Akademisk, 2013. Pris NOK 395 ISBN 978-82-05-44989-3

Tre erfarne fagpersoner innen dette viktige og aktuelle feltet har $i$ tredje utgave av Kunnskapshåndtering $i$ medisin og helsefag gitt studenter, og ikke minst helsearbeidere, et redskap for kunnskapshåndtering i praksis.

Boken fortjener å bli lest som en sammenhengende tekst, da den systematisk bygger opp forståelsen for hele tankegangen bak kunnskapshåndtering. Er man noe kjent med stoffet fra før, vil det helt sikkert også gi utbytte å lese enkeltkapitler. Tonen er diskuterende og problematiserende.

Kompetanse i kunnskapshåndtering skulle være et opplagt ønske for alle helsearbeidere. Her fyller denne lett tilgjengelige teksten på norsk sin plass. Kapittel 1 motiverer leseren til å forstå hvorfor systematisk kunnskapshåndtering er nødvendig og nyttig. De følgende kapitlene er en gjennomgang av hvordan man går frem på en konkret måte. Kapittel 2 er viet til kunsten å stille gode spørsmål, fulgt av kapitler om å gjøre gode søk og å vurdere litteratur grundig samtidig som man unngår å lese inferiør forskning. Sammenhengen mellom spørsmål og studiedesign er grundig behandlet, og leseren får forståelse av verdien av systematiske oversikter og retningslinjer. Vektlegging av pasientens preferanser og hvordan implementere forbedringer er en matnyttig avslutning. Hvert kapittel avsluttes med oppgaver for refleksjon.

Kapittel 3 fortjener en liten klype pepper. Det omhandler innhenting av relevant litteratur. De overordnede betraktningene og forklaringen på forskjeller mellom primær- og sekundærlitteratur er klar. Imidlertid lyktes jeg ikke å følge den praktiske veiledningen i litteratursøk på Helsebibliotekets sider. Her hadde det vært mer hensiktsmessig med henvisning til et oppdatert elektronisk søkekurs på Helsebiblioteket - om et slikt finnes. Et beskrivende register over de mange lenkene til gode nettressurser som nevnes i teksten, ville også vært en nyttig tilføyelse.

Boken er velegnet til å stimulere interesse for kunnskapshåndtering og nyttig for å organisere sine tanker og sin praksis rundt dette. Helsearbeidere fra alle fagfelt vil ha stor glede av denne utgivelsen. Den vil egne seg utmerket i undervisningen av studenter. Den er også et godt grunnlag om man selv skal utarbeide retningslinjer eller sette i gang forbedringsarbeid, selv om man da må påregne å supplere med mer dyptgående litteratur og kursing.

\section{Anne Mette Asfeldt}

Førsteamanuensis II, Institutt for samfunnsmedisin Universitetet i Troms $\emptyset$ - Norges arktiske universitet 